Review

\title{
The efficacy and potential predictive factors of PD-1/PD-L1 blockades in epithelial carcinoma patients: a systematic review and meta analysis
}

\author{
Yufan Yang ${ }^{1, *}$, ZhaoFei Pang ${ }^{1, *}$, Nan Ding ${ }^{1}$, Wei Dong ${ }^{2}$, Wei Ma ${ }^{2}$, Yun Li ${ }^{2}$, Jiajun \\ Du ${ }^{1,2}$ and Qi Liu ${ }^{1}$ \\ ${ }^{1}$ Institute of Oncology, Shandong Provincial Hospital Affiliated to Shandong University, Shandong University, Jinan, Shandong, \\ Peoples's Republic of China \\ 2 Department of Thoracic Surgery, Shandong Provincial Hospital Affiliated to Shandong University, Shandong University, \\ Jinan, Shandong, Peoples's Republic of China \\ 3 Department of Oncology, Shandong Provincial Hospital Affiliated to Shandong University, Shandong University, Jinan, \\ Shandong, Peoples's Republic of China \\ * These authors have contributed equally to this work \\ Correspondence to: Jiajun Du, email: dujiajun@sdu.edu.cn
}

Qi Liv, email: livqi66@sdu.edu.cn

Keywords: PD-1/PD-L1 blockades; epithelial carcinoma; predictive factor; outcome; immunotherapy

Received: May 09, 2016

Accepted: August 11, 2016

Published: August 15, 2016

\section{ABSTRACT}

Background: This systematic analysis aims to assess the efficacy of PD-1/PDL1 blockades compared with non-PD-1/PD-L1 therapy and investigate the potential predictive factors in epithelial carcinoma patients.

Results: A total of 11 trials with 6716 patients of melanoma, non-small cell lung cancer (NSCLC) and renal cell carcinoma (RCC) were included. The pooled HRs $(95 \% \mathrm{CI})$ were $0.67(0.62,0.73), p<0.001$ for OS and $0.66(0.57,0.76), p<0.001$ for PFS. In subgroup analyses, HRs were $0.58(0.50,0.66), p<0.001$ in PD-L1 $\geq$ $1 \%$ group, $0.75(0.63,0.89), p=0.001$ in PD-L1 $<1 \%$ group for OS and $0.59(0.48$, $0.72), p<0.001$ in PD-L1 $\geq 1 \%$ group, $0.80(0.59,1.07), p=0.136$ in PD-L1 $<1 \%$ group for PFS. The $p$ values of pooled HRs for OS in different age, sex and ECOG score groups were less than 0.001. In NSCLC patients, aggregated HRs for OS were 1.40 $(0.92,2.12), p=0.114$ in EGFR mutant group and $0.88(0.59,1.32), p=0.536$ in never smokers.

Methods: A systematic search from January 2010 to April 2016 was conducted for eligible clinical trials. Based on the data of hazard ratios (HRs) and $95 \%$ confidence intervals (CIs) for overall survival (OS) and progression-free survival (PFS), we assessed the pooled HRs and proposed the subgroup analyses.

Conclusions: PD-1/PD-L1 blockades prolonged OS and PFS in epithelial carcinoma patients. PD-L1 expression was a predictive factor for PFS but not predictive for OS. Age, sex and ECOG score were excluded to predict any of the efficacy endpoints. Smoking history and EGFR wild type were associated with extended OS in NSCLC patients.

\section{INTRODUCTION}

The checkpoint immunotherapy has been increasingly understood and used to unleash the immune system to fight against cancer [1]. These years, several immune checkpoints including CTLA-4 and PD-1/PD-L1 were identified and multiple agents have been developed to bind with the immunologic checkpoints and block checkpoint-pathways, which would otherwise impair the $\mathrm{T}$ cell anti-tumor activity. The efficacy of those agents in promoting immune recognition, enhancing the immune response with $\mathrm{T}$ cell and reducing the immune tolerance 
of tumor development has aroused tremendous enthusiasm in cancer treatment nowadays [2].

As one of the most critical checkpoint immunologic treatments, PD-1/PD-L1 blockade has become a promising focus of immunotherapy in cancer treatment [3]. Two antibodies targeting PD-1: nivolumab (Opdivo, BristolMyers Squibb, a fully human monoclonal IgG4 antibody), pembrolizumab (Keytruda, Merck, a humanized monoclonal IgG4 antibody) and an antibody against PD-L1 named atezolizumab (Roche, a fully humanized, engineered monoclonal antibody of $\mathrm{IgG1}$ isotype) have been approved by US Food and Drug Administration (FDA) $[3,4]$. Moreover, at the present time of manuscript, the FDA has approved anti-PD-1/PD-L1 therapy for four histologic types of cancer: melanoma, non-small cell lung cancer (NSCLC), renal cell carcinoma (RCC) and metastatic urothelial carcinoma, all of which are epithelial carcinoma [5].

Almost each of PD-1/PD-L1 blockades has satisfying overall response rates in treating different types of epithelial carcinoma $[6,7]$. However, the outcome of patients treated with PD-1/PD-L1 blockades is still undetermined, for results of several relevant trials show insignificant improvement in prolonging overall survival (OS) and progression free survival (PFS). Besides, it is still urgently necessary to determine which specific group of patients will benefit from the anti-PD-1/PD-L1 therapy. Most of the present systematic studies focus on the response rate and safety of PD-1/PD-L1 blockades or perform single-arm meta-analyses to evaluate the biomarkers. We conduct the systematic analyses with strictly selected randomized controlled trials to clarify the efficacy and factors indicating the outcome of antiPD-1/PD-L1 treatment, compared to other controlled interventions within epithelial carcinoma patients by analyzing HRs for OS or PFS.

In consideration of predictive factors, we analyze different membranous PD-L1 expression levels, because PD-L1 expression of tumor cells is most abundant in epithelial carcinoma and most closely correlated with response to anti-PD-1/PD-L1 agents $[5,8,9]$. Besides, baseline characteristics including age, sex and Eastern Cooperative Oncology Group (ECOG) score are the candidate factors to explore and subgroup analyses of squamous cancer, smoking status, EGFR mutation (within NSCLC patients) and BRAF mutation (within melanoma patients) are also conducted to provide further evidence for clinical treatment.

\section{RESULTS}

\section{Study identification}

According to the outlined search strategy, a total of 820 records were obtained, of which 371 duplicates were removed. After screening, 484 articles including reviews, case reports and non randomized controlled trials were excluded. Of the rest 19 records, 8 studies did not report the relevant data. Upon the remaining 11 studies, the two reviewers had the perfect agreement on their eligibility and assessed the quality of included studies independently by the scoring criteria stated in Cochrane handbook for systematic reviews of interventions. The study selection process was presented in Figure 1. The risk of bias graph and summary of selected studies generated by Revman.5.3 were showed in Figure 2.

\section{Characteristics of studies}

The analyses were based on data from a total of 6716 patients enrolled in 11 randomized controlled trials. The experimental treatment drugs of those trials were PD-1/ PD-L1 blockades, including nivolumab, pembrolizumab and atezolizumab, while the controlled interventions were standard chemotherapy (docetaxel, dacarbazine, etc), targeted therapeutic agents (everolimus) and other form of immunotherapy (ipilimumab). According to currently completed trials focused on epithelial carcinoma, all randomized controlled trials were conducted within melanoma, NSCLC and RCC patients. 6 of the enrolled trials were in melanoma patients $(n=3510), 4$ in NSCLC patients $(n=2385)$, and 1 in RCC patients $(n=821) .3$ of the trials were phase 2 trials, 1 was phase $2 / 3$ trial, and 7 were phase 3 trials.

We collected the basic characteristics of patients in each included trial and extracted information to obtain hazard ratios (HRs) for OS and PFS of patients. For the PD-L1 expression evaluation, the immunohistochemistry assays of PD-L1 employed in the selected studies contained Dako, clone 28-8 (Epitomic) and 22C3 antibody (Merck). We retrieved the corresponding HR estimates with the cut-off of $1 \%$, which meant membranous PDL1 staining in at least $1 \%$ of tumor cells. The information of included studies' authors, cancer types, numbers of patients, interventions, basic characteristics of patients, and HRs for OS and PFS of PD-1/PD-L1 treatment versus non-PD-1/PD-L1 therapy were summarized in Table 1.

\section{Meta-analyses results}

The data available on OS pooling were from 10 observations. The pooled HR for OS (Table 2) was 
Table 1: The patients' characteristics and outcomes data of clinical trials included.

\begin{tabular}{|c|c|c|c|c|c|c|c|c|c|}
\hline \multirow[t]{2}{*}{ First author } & \multirow[t]{2}{*}{ Year } & \multirow[t]{2}{*}{ Total } & \multirow[t]{2}{*}{ Intervention } & \multirow[t]{2}{*}{ Cancer type } & \multirow{2}{*}{$\begin{array}{l}\text { Med } \\
\text { age }\end{array}$} & \multirow{2}{*}{$\begin{array}{l}\text { Sex } \\
\text { (male } \\
[\%])\end{array}$} & \multicolumn{2}{|c|}{ Harzard Ratio $(95 \% \mathrm{Cl})$} & \multirow[t]{2}{*}{ Ref } \\
\hline & & & & & & & OS & PFS & \\
\hline J Brahmer & 2015 & 272 & $\begin{array}{l}\text { nivolumab } 3 \mathrm{mg} / \mathrm{kg} 2 \mathrm{wk} \\
\text { docetaxel } 75 \mathrm{mg} / \mathrm{m}^{2} 3 \mathrm{wk}\end{array}$ & NSCLC & $\begin{array}{l}62 \\
64\end{array}$ & $\begin{array}{l}82 \\
71\end{array}$ & $\begin{array}{l}0.59 \\
(0.44,0.79)\end{array}$ & $\begin{array}{l}0.62 \\
(0.47,0.81)\end{array}$ & [23] \\
\hline H. Borghaei & 2015 & 792 & $\begin{array}{l}\text { nivolumab } 3 \mathrm{mg} / \mathrm{kg} 2 \mathrm{wk} \\
\text { docetaxel } 75 \mathrm{mg} / \mathrm{m}^{2} 3 \mathrm{wk}\end{array}$ & NSCLC & $\begin{array}{l}61 \\
64\end{array}$ & $\begin{array}{l}52 \\
58\end{array}$ & $\begin{array}{l}0.73 \\
(0.60,0.89)\end{array}$ & $\begin{array}{l}0.92 \\
(0.77,1.10)\end{array}$ & [24] \\
\hline R S Herbst & 2016 & 1034 & $\begin{array}{l}\text { pembrolizumab } 2 \mathrm{mg} / \mathrm{kg} \\
\text { pembrolizumab } 10 \mathrm{mg} / \mathrm{kg} \\
\text { docetaxel }\end{array}$ & NSCLC & $\begin{array}{l}63 \\
65 \\
62\end{array}$ & $\begin{array}{l}62 \\
62 \\
61\end{array}$ & $\begin{array}{l}0.71 \\
(0.58,0.88) \\
0.61 \\
(0.49,0.75)\end{array}$ & $\begin{array}{l}0.88 \\
(0.74,1.05) \\
0.79 \\
(0.66,0.94)\end{array}$ & [25] \\
\hline L Fehrenbacher & 2016 & 287 & $\begin{array}{l}\text { atezolizumab } 1200 \mathrm{mg} \\
\text { docetaxel } 75 \mathrm{mg} / \mathrm{m}^{2} 3 \mathrm{wk}\end{array}$ & NSCLC & $\begin{array}{l}62 \\
143\end{array}$ & $\begin{array}{l}65 \\
53\end{array}$ & $\begin{array}{l}0.73 \\
(0.53,0.99)\end{array}$ & $\begin{array}{l}0.94 \\
(0.72,1.23)\end{array}$ & [26] \\
\hline J. Larkin & 2015 & 945 & $\begin{array}{l}\text { nivolumab 3mg/kg } 2 w k \\
\text { nivolumab } 1 \mathrm{mg} / \mathrm{kg} 3 w \mathrm{k}+ \\
\text { ipilimumab 3mg/kg 3wk } \\
\text { ipilimumab 3mg/kg 3wk }\end{array}$ & melanoma & $\begin{array}{l}59 \\
59 \\
61\end{array}$ & $\begin{array}{l}63.9 \\
65.6 \\
64.1\end{array}$ & $\begin{array}{l}0.65 \\
(0.39,1.08)\end{array}$ & $\begin{array}{l}0.57 \\
(0.43,0.76)\end{array}$ & {$[10]$} \\
\hline C. Robert & 2015 & 418 & $\begin{array}{l}\text { nivolumab 3mg/kg } 2 \mathrm{wk} \\
\text { dacarbazine } 1000 \mathrm{mg} / \mathrm{m}^{2} 3 \mathrm{wk}\end{array}$ & melanoma & $\begin{array}{l}64 \\
66\end{array}$ & $\begin{array}{l}57.6 \\
60.1\end{array}$ & $\begin{array}{l}0.42 \\
(0.25,0.73)\end{array}$ & $\begin{array}{l}0.43 \\
(0.34,0.56)\end{array}$ & [27] \\
\hline C. Robert & 2015 & 834 & $\begin{array}{l}\text { pembrolizumab } 10 \mathrm{mg} / \mathrm{kg} 2 \mathrm{wk} \\
\text { pembrolizumab } 10 \mathrm{mg} / \mathrm{kg} 3 w \mathrm{k} \\
\text { ipilimumab } 3 \mathrm{mg} / \mathrm{kg} 3 w \mathrm{k}\end{array}$ & melanoma & $\begin{array}{l}61 \\
63 \\
62\end{array}$ & $\begin{array}{l}57.7 \\
62.8 \\
58.3\end{array}$ & $\begin{array}{l}0.63 \\
(0.47,0.83) \\
0.69 \\
(0.52,0.90)\end{array}$ & $\begin{array}{l}0.58 \\
(0.46,0.72) \\
0.58 \\
(0.47,0.72)\end{array}$ & [28] \\
\hline M A. Postow & 2015 & 142 & $\begin{array}{l}\text { nivolumab } 1 \text { mg/kg+ } \\
\text { ipilimumab 3mg/kg } \\
\text { ipilimumab 3mg/kg }\end{array}$ & melanoma & $\begin{array}{l}64 \\
67\end{array}$ & $\begin{array}{l}66 \\
68\end{array}$ & N/A & $\begin{array}{l}0.40 \\
(0.23,0.68) \\
0.38 \\
(0.15,1.00)\end{array}$ & [29] \\
\hline A Ribas & 2015 & 540 & $\begin{array}{l}\text { pembrolizumab } 2 \mathrm{mg} / \mathrm{kg} 3 \mathrm{wk} \\
\text { pembrolizumab } 10 \mathrm{mg} / \mathrm{kg} 3 \mathrm{wk} \\
\text { IC chemotherapy }\end{array}$ & melanoma & $\begin{array}{l}62 \\
60 \\
63\end{array}$ & $\begin{array}{l}58 \\
60 \\
64\end{array}$ & $\mathrm{~N} / \mathrm{A}$ & $\begin{array}{l}0.57 \\
(0.45,0.73) \\
0.50 \\
(0.39,0.64)\end{array}$ & [30] \\
\hline JS Weber & 2015 & 631 & $\begin{array}{l}\text { Nivolumab } 3 \mathrm{mg} / \mathrm{kg} 2 \mathrm{wk} \\
\text { IC chemotherapy }\end{array}$ & melanoma & $\begin{array}{l}59 \\
62\end{array}$ & $\begin{array}{l}65 \\
64\end{array}$ & $N / A$ & $\begin{array}{l}0.82 \\
(0.40,1.66)\end{array}$ & {$[31]$} \\
\hline R. J. Motzer & 2015 & 821 & $\begin{array}{l}\text { nivolumab } 3 \mathrm{mg} / \mathrm{kg} 2 \mathrm{wk} \\
\text { everolimus } 10 \mathrm{mg}\end{array}$ & $\mathrm{RCC}$ & $\begin{array}{l}62 \\
62\end{array}$ & $\begin{array}{l}77 \\
74\end{array}$ & $\begin{array}{l}0.73 \\
(0.60,0.89)\end{array}$ & $\begin{array}{l}0.88 \\
(0.75,1.03)\end{array}$ & [32] \\
\hline
\end{tabular}

Abbreviations: NSCLC=non-small cell lung cancer, RCC=renal cell carcinoma, OS=overall survival, PFS=progression free survival, Ref=

reference. 
Table 2: the pooled results of HRs for OS and PFS of the included trials.

\begin{tabular}{|c|c|c|c|c|c|c|c|c|}
\hline $\begin{array}{l}\text { Outcome } \\
\text { endpoint }\end{array}$ & $\begin{array}{l}\text { Cancer } \\
\text { Type }\end{array}$ & Subgroup & $\begin{array}{l}\text { Number of } \\
\text { observations }\end{array}$ & \begin{tabular}{|l|}
$\left.\begin{array}{l}\text { Publication } \\
\text { bias } \\
(P>|t|\end{array}\right) *$ \\
\end{tabular} & HR, (95\%CI) & $p$ & $\begin{array}{l}\text { Pooling } \\
\text { model }\end{array}$ & $\mathbf{I}^{2 \%} \%$ \\
\hline$\overline{\mathrm{OS}}$ & All types & -- & 10 & 0.064 & $0.67,(0.62,0.73)$ & 0.000 & Fixed & 0.0 \\
\hline OS & All types & $\begin{array}{l}\text { PD-L1 } \\
\text { expression } \geq 1 \% \\
\text { PD-L1 } \\
\text { expression }<1 \% \\
\end{array}$ & $\begin{array}{l}5 \\
5\end{array}$ & $\begin{array}{l}0.929 \\
0.046\end{array}$ & $\begin{array}{l}0.58,(0.50,0.66) \\
0.75,(0.63,0.89)\end{array}$ & $\begin{array}{l}0.000 \\
0.001\end{array}$ & Fixed & $\begin{array}{l}5.6 \\
0.0\end{array}$ \\
\hline OS & All types & $\begin{array}{l}\text { Age } \geq 65 \\
\text { Age }<65\end{array}$ & $\begin{array}{l}5 \\
7\end{array}$ & $\begin{array}{l}0.291 \\
0.857\end{array}$ & $\begin{array}{l}0.72,(0.64,0.82) \\
0.70,(0.60,0.81)\end{array}$ & $\begin{array}{l}0.000 \\
0.000\end{array}$ & Fixed & $\begin{array}{l}0.0 \\
0.0\end{array}$ \\
\hline OS & All types & \begin{tabular}{|l} 
Male \\
Female \\
\end{tabular} & $\begin{array}{l}5 \\
5 \\
\end{array}$ & $\begin{array}{l}0.366 \\
0.775 \\
\end{array}$ & $\begin{array}{l}0.68,(0.60,0.77) \\
0.75,(0.64,0.88)\end{array}$ & $\begin{array}{ll}0.000 \\
0.000\end{array}$ & Fixed & $\begin{array}{l}0.0 \\
0.0\end{array}$ \\
\hline OS & All types & $\begin{array}{l}\text { ECOG score }=0 \\
\text { ECOG score }=1\end{array}$ & $\begin{array}{l}4 \\
4 \\
\end{array}$ & $\begin{array}{l}0.181 \\
0.829 \\
\end{array}$ & $\begin{array}{l}0.67,(0.56,0.80) \\
0.69,(0.60,0.80)\end{array}$ & $\begin{array}{ll}0.000 \\
0.000\end{array}$ & Fixed & $\begin{array}{l}0.0 \\
0.0\end{array}$ \\
\hline OS & NSCLC & $\begin{array}{l}\text { Squamous } \\
\text { Non-squamous }\end{array}$ & \begin{tabular}{|l}
3 \\
3
\end{tabular} & $\begin{array}{l}0.865 \\
0.162\end{array}$ & $\begin{array}{l}0.67,(0.54,0.82) \\
0.69,(0.60,0.79)\end{array}$ & $\begin{array}{l}0.000 \\
0.000\end{array}$ & Fixed & $\begin{array}{l}0.0 \\
0.0\end{array}$ \\
\hline OS & NSCLC & $\begin{array}{l}E G F R \text { wild type } \\
E G F R \text { mutant type }\end{array}$ & $\begin{array}{l}2 \\
2\end{array}$ & $\begin{array}{l}- \\
--\end{array}$ & $\begin{array}{l}0.66,(0.57,0.77) \\
1.40,(0.92,2.12)\end{array}$ & $\begin{array}{l}0.000 \\
0.114\end{array}$ & Fixed & $\begin{array}{l}0.0 \\
67.3\end{array}$ \\
\hline OS & NSCLC & $\begin{array}{l}\text { Smoker } \\
\text { Never-Smoker }\end{array}$ & $\begin{array}{l}2 \\
2\end{array}$ & $\begin{array}{l}- \\
-- \\
-\end{array}$ & $\begin{array}{l}0.71,(0.60,0.86) \\
0.88,(0.59,1.32)\end{array}$ & $\begin{array}{l}0.000 \\
0.536\end{array}$ & Fixed & $\begin{array}{l}0.0 \\
39.0\end{array}$ \\
\hline PFS & \begin{tabular}{|l|} 
All types \\
\end{tabular} & -- & 15 & 0.063 & $0.66,(0.57,0.76)$ & 0.000 & Random & 79.7 \\
\hline PFS & $\begin{array}{l}\text { Melanoma } \\
\text { NSCLC } \\
\text { RCC } \\
\end{array}$ & -- & $\begin{array}{l}9 \\
5 \\
1 \\
\end{array}$ & \begin{tabular}{|l|}
0.668 \\
0.488 \\
-- \\
\end{tabular} & $\begin{array}{l}0.54,(0.49,0.59) \\
0.84,(0.77,0.92) \\
0.84,(0.75,1.03)\end{array}$ & \begin{tabular}{l|}
0.000 \\
0.000 \\
0.114
\end{tabular} & Fixed & $\begin{array}{l}0.0 \\
44.4 \\
-- \\
\end{array}$ \\
\hline PFS & All types & $\begin{array}{l}\text { PD-L1 } \\
\text { expression } \geq 1 \% \\
\text { PD-L1 } \\
\text { expression }<1 \%\end{array}$ & $\begin{array}{l}3 \\
3\end{array}$ & $\begin{array}{l}0.183 \\
0.236\end{array}$ & $\begin{array}{l}0.59,(0.48,0.72) \\
0.80,(0.59,1.07)\end{array}$ & $\begin{array}{l}0.000 \\
0.136\end{array}$ & Fixed & $\begin{array}{l}0.0 \\
0.0\end{array}$ \\
\hline PFS & All types & $\begin{array}{l}\text { Age } \geq 65 \\
\text { Age }<65 \\
\end{array}$ & $\begin{array}{l}5 \\
5 \\
\end{array}$ & $\begin{array}{l}0.050 \\
0.000 \\
\end{array}$ & $\begin{array}{l}0.57,(0.44,0.74) \\
0.69,(0.56,0.84)\end{array}$ & $\begin{array}{ll}0.000 \\
0.000\end{array}$ & Random & $\begin{array}{l}77.6 \\
46.8 \\
\end{array}$ \\
\hline PFS & All types & $\begin{array}{l}\text { Male } \\
\text { Female } \\
\end{array}$ & $\begin{array}{l}5 \\
5 \\
\end{array}$ & \begin{tabular}{|l|}
0.001 \\
0.073 \\
\end{tabular} & $\begin{array}{l}0.60,(0.49,0.72) \\
0.67,(0.51,0.87) \\
\end{array}$ & $\begin{array}{ll}0.000 \\
0.002 \\
\end{array}$ & Random & $\begin{array}{l}54.6 \\
66.3 \\
\end{array}$ \\
\hline PFS & All types & $\begin{array}{l}\text { ECOG score }=0 \\
\text { ECOG score }=1\end{array}$ & $\begin{array}{l}5 \\
5\end{array}$ & $\begin{array}{l}0.541 \\
0.028\end{array}$ & $\begin{array}{l}0.64,(0.48,0.84) \\
0.65,(0.56,0.75)\end{array}$ & \begin{tabular}{l|}
0.001 \\
0.000
\end{tabular} & Random & $\begin{array}{l}77.3 \\
18.4\end{array}$ \\
\hline PFS & Melanoma & $\begin{array}{l}B R A F \text { wild type } \\
B R A F \text { mutant type }\end{array}$ & $\begin{array}{l}5 \\
6 \\
\end{array}$ & \begin{tabular}{|l|}
0.632 \\
0.342 \\
\end{tabular} & $\begin{array}{l}0.51,(0.45,0.58) \\
0.55,(0.44,0.69)\end{array}$ & $\begin{array}{ll}0.000 \\
0.000\end{array}$ & Fixed & $\begin{array}{l}2.7 \\
8.0\end{array}$ \\
\hline
\end{tabular}

0.67 , $(95 \% \mathrm{CI}, 0.62,0.73 ; p<0.001)$ without significant heterogeneity $\left(\mathrm{I}^{2}<0.1 \%\right)$, which reflected that compared to non-PD-1/PD-L1 therapy, PD-1/PD-L1 blockades reduced $33 \%$ in risk of death among epithelial carcinoma patients. This benefit had met the criteria of treatment superiority.

All studies reported the data on PFS, and the combined HR for PFS with 15 records was 0.66 , (95\% CI, 0.57, 0.76; $p<0.001)$. However, a considerable heterogeneity with $\mathrm{I}^{2}=79.7 \%$ was observed with the random effect model (Figure 3A). Hence, we conducted the subgroup analyses to investigate the cause of heterogeneity and divided the studies into different cancer types (melanoma, NSCLC and RRC). The results of different types analyses had moderate within-group heterogeneities with $\mathrm{I}^{2}<0.1 \%$ for melanoma and $44 \%$ for NSCLC. The computed HRs $(95 \% \mathrm{CI}$; $\mathrm{p})$ for PFS in melanoma, NSCLC and RCC were $0.54(0.49,0.59 ; p<$ $0.001), 0.84$ (0.77, 0.92; $p<0.001), 0.84(0.75,1.03 ; p=$
$0.114)$ respectively.

To investigate predictive role of PD-L1 expression, we computed the aggregated HRs for OS and PFS in different levels of PD-L1 expression ( $\geq 1 \%,<1 \%$ ) groups and generated the forest plot (Figure 4). Pooled HRs $(95 \% \mathrm{CI} ; \mathrm{p})$ were $0.58,(0.50,0.66 ; p<0.001)$ in PD-L1 $\geq 1 \%$ group, $0.75,(0.63,0.89 ; p=0.001)$ in PD-L1 $<1 \%$ group for OS and $0.59,(0.48,0.72 ; p<0.001)$ in PD-L1 $\geq 1 \%$ group, $0.80,(0.59,1.07 ; p=0.136)$ in $\mathrm{PD}-\mathrm{L} 1<1 \%$ group for PFS with not important heterogeneity within all subgroups $\left(\mathrm{I}^{2}=5.6 \%, 0.0 \%, 0.0 \%, 0.0 \%\right)$.

We also analyzed the baseline data such as age, sex and ECOG score of 0 or 1 (on a 5-point scale, with higher scores indicating greater disability) to further explore other factors. The results of pooled HRs for OS and PFS corresponding to these factors were listed in table 2 and the effects of anti-PD-1/PD-L1 therapy in all those subgroups were favorable and did not have significantly changes between different ages, sexes and ECOG scores 
groups.

Among the NSCLC patients, both the squamous patients $(\mathrm{HR}(95 \% \mathrm{CI})=0.67,(0.54,0.82) ; p<0.001)$ and non-squamous patients $(0.69,(0.60,0.79) ; p<0.001)$ had more extended OS when compared with non-PD-1/PD-L1 therapy. In $E G F R$ wild type patients, the HR for OS was $0.66,(0.57,0.77) ; p<0.001$, indicating the better efficacy of PD-1/PD-L1 blockades in those patients. However, in patients with $E G F R$ mutant type, the HR for OS was $1.40,(0.92,2.12)$ and $\mathrm{p}$ was $0.114\left(\mathrm{I}^{2}\right.$ of heterogeneity $=67.3 \%)$, suggesting that anti-PD-1/PD-L1 therapy functioned not distinctly better than the control group treatment. Similarly, the never-smokers were verified not to have the expectedly longer OS with HR pooled as $0.88,(0.59,1.32) ; p=0.536$ with $\mathrm{I}^{2}=39.0 \%$. The HR for OS in smokers was $0.71,(0.60,0.86) ; p<0.001$ with the meaning of better outcomes due to the use of antiPD-1/PD-L1 agents. Besides, in melanoma patients, both the $B R A F$ wild type and $B R A F$ mutant patients benefited in OS, and HRs (95\%CIs) were $0.51,(0.45,0.58), p<$ $0.001 ; 0.55,(0.44,0.69), p<0.001$ respectively with not important heterogeneity $\left(\mathrm{I}^{2}=2.7 \% ; \mathrm{I}^{2}=8.0 \%\right)$ (Figure 5$)$.

All reported data of the meta-analyses results were listed in Table 2 with the relative details and models adopted.

\section{Sensitivity analyses}

The sensitivity analyses were conducted by excluding studies one by one. The results of those analyses showed no significant differences when compared to the former summary estimates and had excellent stability.

\section{Publication bias}

We assessed the publication bias of included data for pooled analyses using the Egger's test, and the $p$

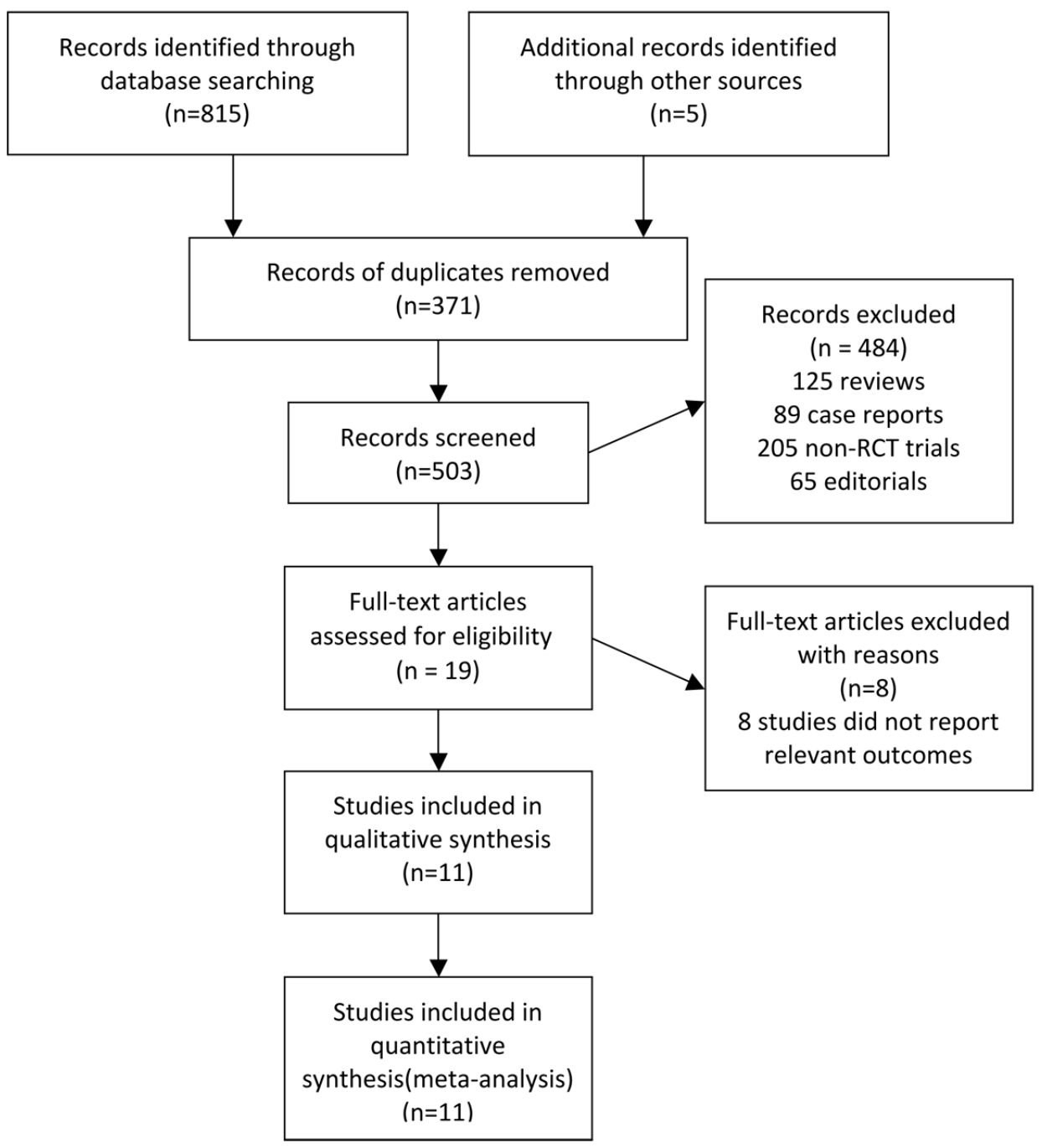

Figure 1: Flowchart of study selection procedure. 
values were listed in table 2 . In the light of data computed and listed, there was no substantial publication bias ( $p<$ 0.05 ) in our main analyses. Nevertheless, two possible biases with $p<0.05$ by Egger's test were observed in the subgroups of Age $<65$ and Male patients in the pooling process of HR for PFS.

\section{DISCUSSION}

It was acknowledged that PD-1/PD-L1 blockade, as a type of immune checkpoint inhibitors, had remarkable response rate and clinical results in patients with different kinds of cancer, especially those with epithelial-originated malignancies. Nonetheless, it remained unclear whether anti-PD-1/PD-L1 therapy, in contrast with other therapy, functioned better to extend OS and PFS and which subgroups of patients would benefit from the treatment. Our meta-analysis integrating all data from relevant trials were requested to solve the problem. To our knowledge, the meta-analysis was the first study to investigate the outcome and predictive biomarkers for PD-1/PD-L1 therapy in epithelial carcinoma patients within solely randomized controlled trials by assessing the two primary endpoints of OS and PFS.

Our results provided convincing evidence that the OS of patients given PD-1/PD-L1 inhibitors was

Risk of bias graph

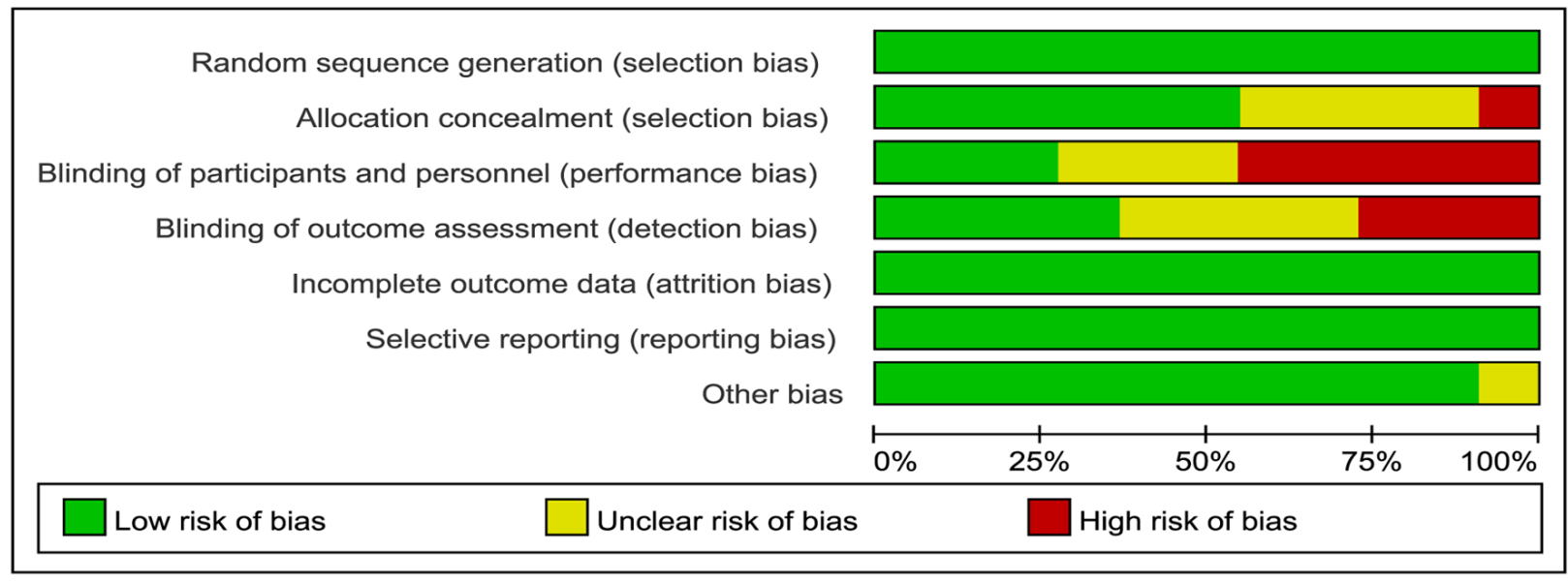

Risk of bias summary

\begin{tabular}{|c|c|c|c|c|c|c|c|c|c|c|c|}
\hline 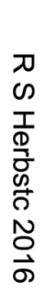 & 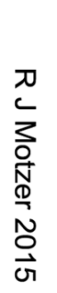 & 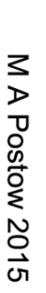 & 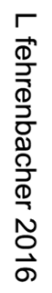 & 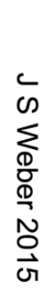 & 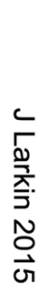 & 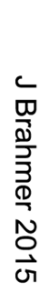 & 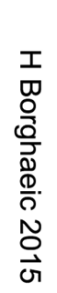 & 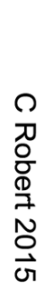 & 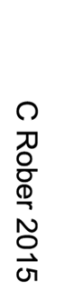 & 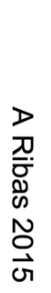 & \\
\hline+ & + & + & + & + & + & + & + & + & + & + & Random sequence generation (selection bias) \\
\hline$\sim$ & + & + & & + & + & + & $v$ & $v$ & $\sim$ & + & Allocation concealment (selection bias) \\
\hline & & + & & & + & $\sim$ & & $\sim$ & $\sim$ & + & Blinding of participants and personnel (performance bias) \\
\hline & $\nu$ & + & & + & + & $v$ & & $\nu$ & $\nu$ & + & Blinding of outcome assessment (detection bias) \\
\hline 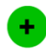 & + & + & + & + & + & + & + & + & + & + & Incomplete outcome data (attrition bias) \\
\hline 1 & + & + & + & + & + & + & + & + & + & + & Selective reporting (reporting bias) \\
\hline+ & + & + & + & + & + & + & $-v$ & + & + & + & Other bias \\
\hline
\end{tabular}

Figure 2: Risk of bias graph and summary of included clinical trials. 
A Study

$\mathrm{HR}(95 \% \mathrm{Cl})$

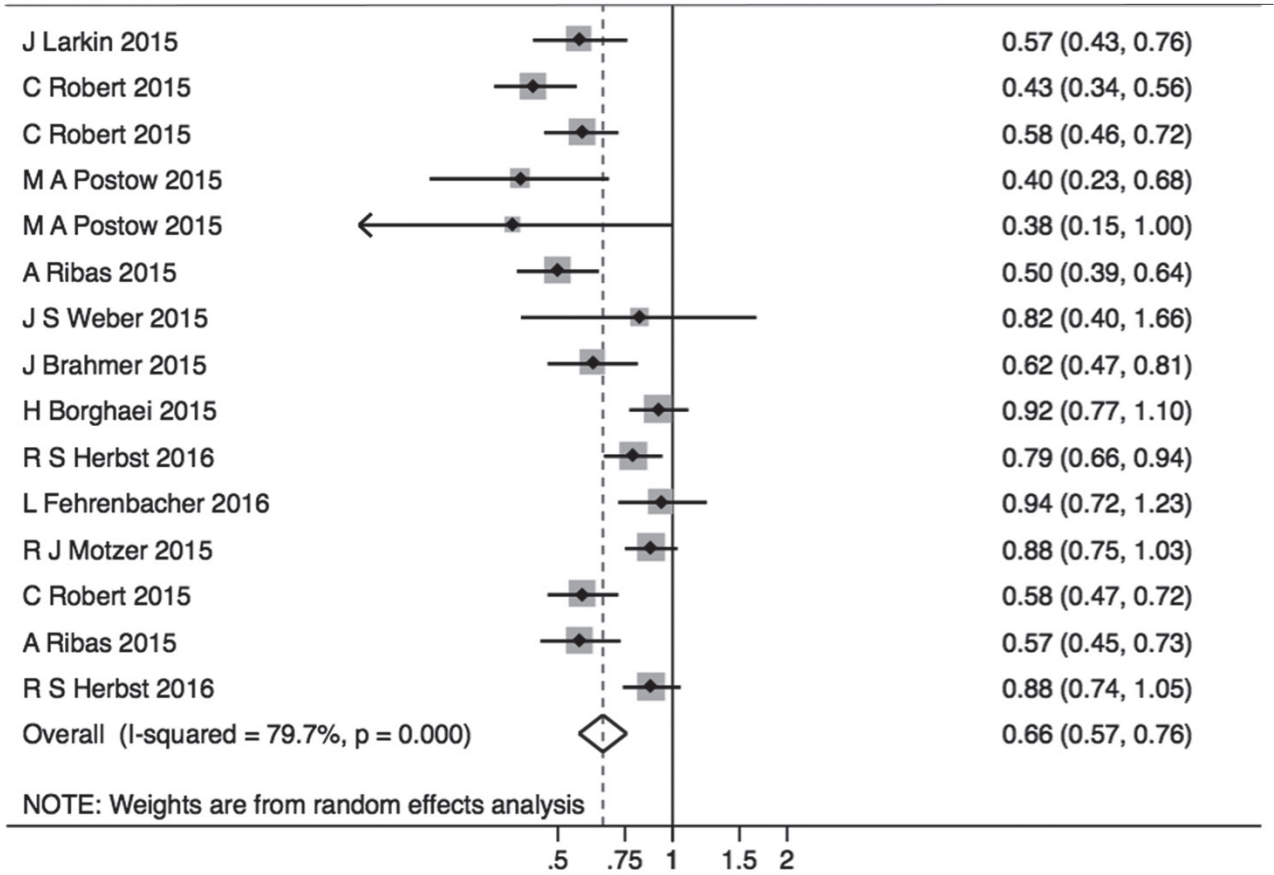

B Study

ID

$\mathrm{HR}(95 \% \mathrm{Cl})$

\begin{tabular}{|c|c|}
\hline \multirow{2}{*}{\multicolumn{2}{|c|}{ Melanoma }} \\
\hline & \\
\hline J Larkin 2015 & $0.57(0.43,0.76)$ \\
\hline C Robert 2015 & $0.43(0.34,0.56)$ \\
\hline C Robert 2015 & $0.58(0.46,0.72)$ \\
\hline M A Postow 2015 & $0.40(0.23,0.68)$ \\
\hline M A Postow 2015 & $0.38(0.15,1.00)$ \\
\hline A Ribas 2015 & $0.50(0.39,0.64)$ \\
\hline J S Weber 2015 & $0.82(0.40,1.66)$ \\
\hline C Robert 2015 & $0.58(0.47,0.72)$ \\
\hline A Ribas 2015 & $0.57(0.45,0.73)$ \\
\hline Subtotal (I-squared $=0.0 \%, p=0.461$ ) & $0.54(0.49,0.59)$ \\
\hline \multicolumn{2}{|l|}{ NSCLC } \\
\hline J Brahmer 2015 & $0.62(0.47,0.81)$ \\
\hline H Borghaei 2015 & $0.92(0.77,1.10)$ \\
\hline R S Herbst 2016 & $0.79(0.66,0.94)$ \\
\hline L Fehrenbacher 2016 & $0.94(0.72,1.23)$ \\
\hline R S Herbst 2016 & $0.88(0.74,1.05)$ \\
\hline Subtotal $(\mathrm{I}-$ squared $=44.4 \%, p=0.126$ ) & $0.84(0.77,0.92)$ \\
\hline \multicolumn{2}{|l|}{ RCC } \\
\hline R J Motzer 2015 & $0.88(0.75,1.03)$ \\
\hline Subtotal $($ I-squared $=. \%, p=)$. & $0.88(0.75,1.03)$ \\
\hline Heterogeneity between groups: $p=0.000$ & \\
\hline Overall (I-squared $=79.7 \%, p=0.000$ ) & $0.71(0.66,0.75)$ \\
\hline
\end{tabular}

Figure 3: Forest plots of A. hazard ratio (HR) for PFS; B. HRs for PFS in subgroups of different types of epithelial carcinoma. 
significantly longer than patients given other drugs as those individual studies reported (only one study comparing nivolumab with ipilimumab (CTLA-4 antibody) [10] excluded). The effect of PD-1/PD-L1 inhibitors on prolonging PFS was controversial among the 15 observations from 11 enrolled trials and our aggregated HR affirmed the efficacy to extend PFS in epithelial carcinoma patients. However, the heterogeneity of the studies was significant and we conducted the subgroup analyses stratified by different cancer types to figure out this issue. The results of subgroup analyses indicated that both the melanoma and NSCLC patients could obtain longer PFS due to the use of PD-1/PD-L1 blockades. Whilst HR for PFS in one RCC trial suggested that no difference in PFS between the two interventions existed.

In PD-L1 expression investigation, we found it not practicable to use PD-L1 as a biomarker to predict OS benefit when comparing PD-1/PD-L1 blockades with other control therapy, for both the higher (PD-L1 expression $\geq 1 \%$ ) and lower (PD-L1 expression $<1 \%$ ) expression groups could gain obvious clinical benefit from PD-1/ PD-L1 blockades. Be that as it may, the higher expression group had the better PFS outcome, but the lower expression group was associated with insubstantial improvement of PFS. The immunohistochemistry (IHC) cut-off value (ranging from $1 \%$ to $50 \%$ ) we chose to define the PDL1 positivity was $1 \%$, in that the clinical data assessed by this point were the most abundant in the included 11

Study

ID

$\mathrm{HR}(95 \% \mathrm{Cl})$

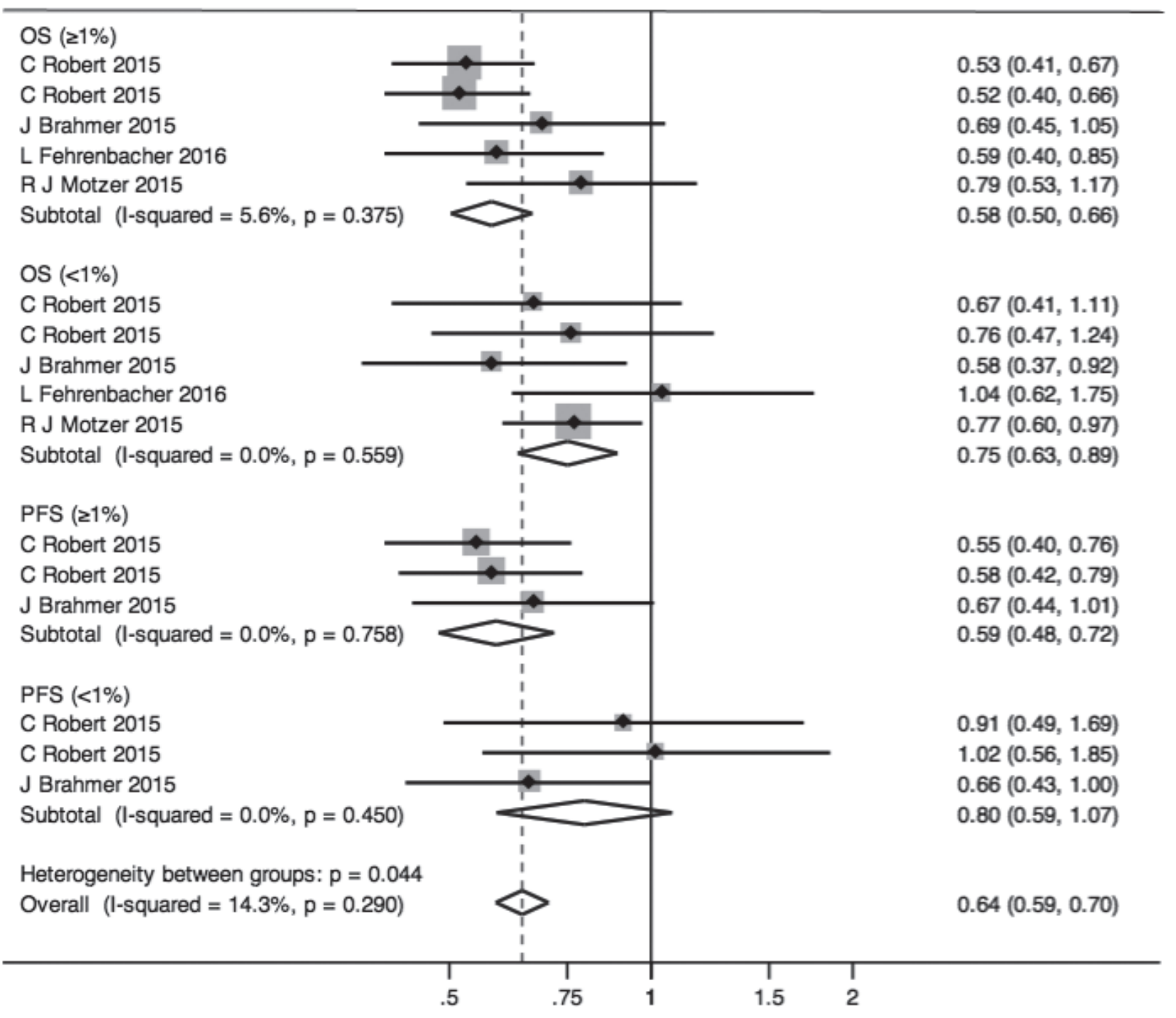

Figure 4: Forest plots of HRs for OS and PFS in the subgroups of patients with PD-L1 expression $\geq 1 \%$ and $<1 \%$. 
trials. Besides, cutting off by the lowest expression level enabled to include the most possible patients who could benefit from the therapy. However, the assessment of PDL1 expression was much complicated because the tumor PD-L1 expression was not constant which was associated with activated tumor antigen-specific $\mathrm{T}$ cells $[11,12]$ and could be induced by specific agents such as interferon [13]. In addition, the degree of PD-L1 expression could be heterogeneous between different types of cancer or even primary and metastatic lesions in one type of cancer [12]. As for detection methods, there were still many limitations of IHC detection such as the low efficacy caused by the two small hydrophilic regions of PD-L1 antibody and the bias caused by different proprietary assays in different trials $[14,15]$. Several associations were focusing on standardizing and validating a reliable IHC assay of PDL1 expression currently [16]. The combination of IHC and gene amplification as the detection method adopted in

Study

ID

$\mathrm{HR}(95 \% \mathrm{Cl})$

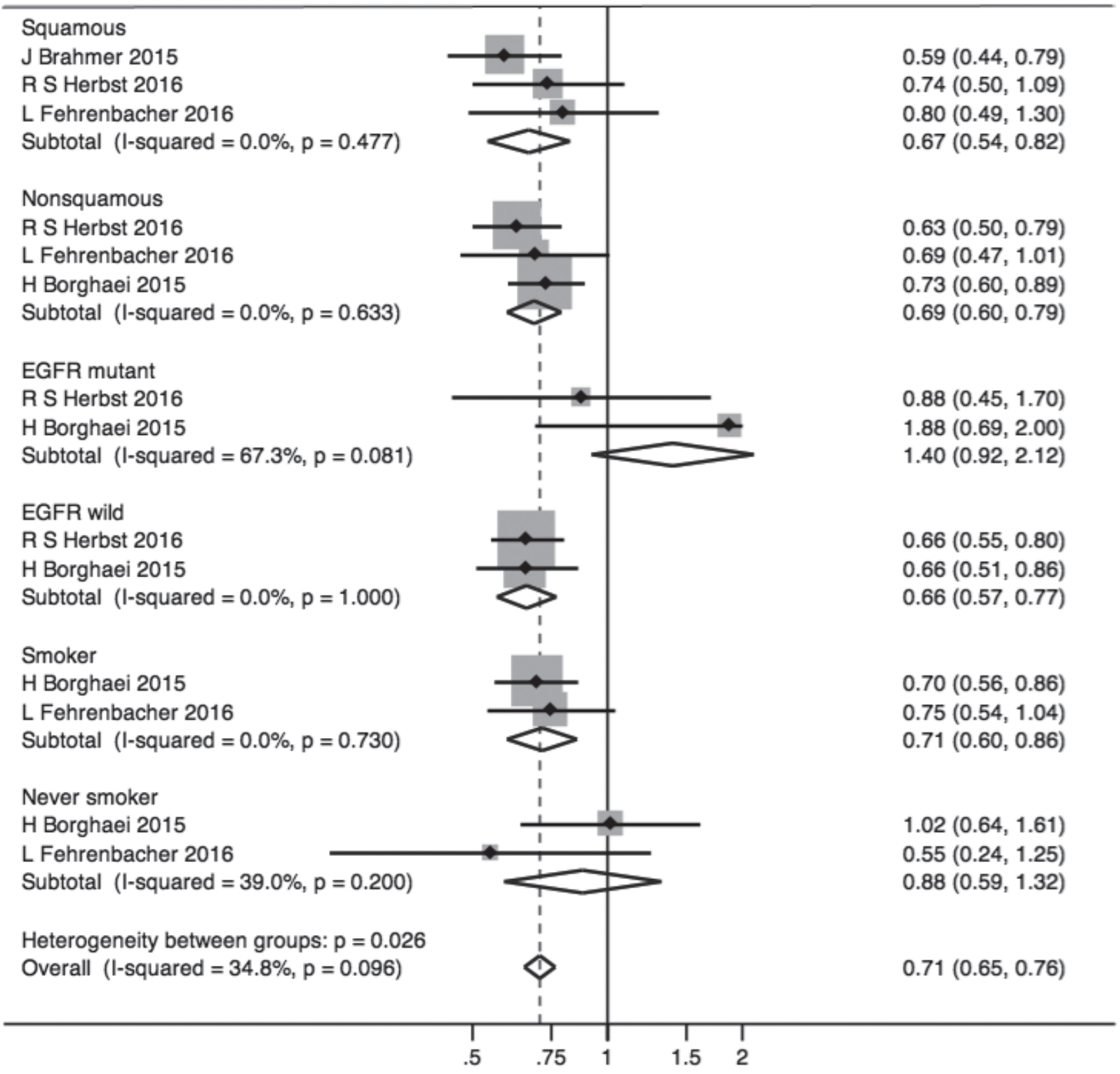

Figure 5: Forest plots of HRs for OS in squamous, non-squamous, EGFR mutant, EGFR wild, Smoker and never smoker NSCLC subgroup patients. 
HER-2 status assessment in gastric and breast cancers [17, 18] also gave the instruction for PD-L1 detection [19, 20]. Thus, the further experiments focused on the expression mechanism and detection were needed to draw more definitive conclusion.

The next novel finding of our analyses was in different subgroups. We found that the $B R A F$ mutant or $B R A F$ wild type patients in melanoma group, and the squamous cancer patient or non-squamous cancer patients in NSCLC group had gained better outcome of survival. But there was no significant improvement for OS in patients without smoking history and patients with EGFR mutations. Whilst, the present or previous smoker, patients with $E G F R$ wild type showed longer survival time, implicating the smoking history and EGFR wild type might be considered as the potential predictive factors for anti-PD-1/PD-L1 treatment. In our speculation, the association of mutations and other exposures to mutagens like smoking with the efficacy of PD-L1 blockades was possibly because the tumor antigen, considered as the target of $\mathrm{T}$ cell activated by checkpoint blockade, was related to the consequence of somatic mutations $[19,21$, $22]$. However, the limited number of observations in our subgroup analyses still required prospective validation with larger scale investigations.

Finally, OS had been improved in the overall patient regardless of the age, sex and ECOG score. Thus, it was persuasive that those factors were not meaningful indicators for the eligibility of anti-PD-1/PD-L1 treatment.

In conclusion, the aggregated HRs for OS and PFS summarized in our systematic analyses revealed that in the comparison of anti-PD-1/PD-L1 agents with other control therapy, the PD-L1 expression was not an appropriate factor to predict the benefit of OS in epithelial carcinoma patients, but could be predictive for PFS. Age, sex and ECOG score were excluded to predict any of the outcome endpoints. Smoking history and EGFR wild type were potential indicators for prolonged OS in NSCLC patients. There were multiple clinical trials ongoing and many other antibodies targeting PD-1/PD-L1 under early-stage development currently, more comprehensive data from future clinical trials focused on this field were still needed for further investigation.

\section{MATERIALS AND METHODS}

\section{Publications search}

We searched for the articles of clinical trials from PubMed, Embase, Web of Science, and the Cochrane Library from January 2010 to April 2016. Records at American Society of Clinical Oncology (ASCO), the European Society for Medical Oncology (ESMO), the world Conference of Lung cancer (WCLC) were also reviewed. The following search terms were used: "pembrolizumab", "Nivolumab" "atezolizumab", "Tremelimumab", “AMP-224”,"MDX-1105", "pidilizumab", and "cancer/ carcinoma".

\section{Study selection}

All relevant articles underwent evaluation for eligibility by two investigators independently and we selected the articles according to the following criteria: 1) articles with randomized controlled trials (RCTs); 2) at least one of the two endpoints (PFS, OS) reported; 3) published in English; 4) the full text available. Our exclusion criteria were as below: 1) letters, expert opinions, case reports and reviews; 2) articles without available data; 3 ) duplicate publications.

\section{Quality assessment}

We assessed the quality of involved randomized controlled clinical trials according to the criteria presented in the Cochrane Handbook for Systematic Reviews of Interventions (version 5.1.0; chapter 8), and evaluated the random sequence generation, allocation concealment, blinding of participants and personnel, blinding of outcome assessment, incomplete outcome data, selective reporting and other bias to ensure the low-risk of bias of the studies included.

\section{Data extraction}

The data of study identification, the intervention of experimental treatment and control group, numbers of enrolled patients in each trial, patients' detailed information (age, sex, line of therapy and ECOG score), hazard ratios(HR) with their $95 \%$ CIs and $p$ values for OS and PFS were extracted by two individual investigators independently. We also collected the relevant information in every subgroup we set to render sufficient data to our subgroup analyses.

\section{Statistical analysis}

We calculated pooled HRs and their 95\%CIs for OS and PFS which were considered to be the primary outcome of the meta-analyses and generated the forest plots accordingly. The chi-square $\mathrm{Q}$ test and $\mathrm{I}^{2}$ statistic were used to indicate the heterogeneity. A p value less than 0.05 in the $\mathrm{Q}$ test or an $\mathrm{I}^{2}$ value greater than $50 \%$ in the $\mathrm{I}^{2}$ statistics suggested the significant heterogeneity. If the heterogeneity was significant, we used the random effect model of pooling instead of fixed effect model and designed subgroups analyses to clarify the between-study 
heterogeneity. To test the publication bias of the included studies, the Egger's test was chosen. All the statistical analyses were performed with STATA/SE software version12.0 (STATA Corporation, College Station, TX, USA).

\section{ACKNOWLEDGMENTS}

This work was supported by Provincial science and technology development plan of Shandong (2015GSF118063), Foundation for Outstanding Young Scientist in Shandong Province (BS2013YY066) and Medicine and Health Science Technology Development Plan of Shandong Province (2013WS0103).

\section{CONFLICTS OF INTEREST}

We declared that we had no financial and personal relationships with other people or organizations that could inappropriately influence our work. There was no professional or other personal interest of any nature or kind in any product, service and/or company that could be construed as influencing the position presented in, or the review of this manuscript.

\section{REFERENCES}

1. Couzin-Frankel J. Breakthrough of the year 2013. Cancer immunotherapy. Science (New York, NY). 2013; 342(6165):1432-1433.

2. Postow MA, Callahan MK and Wolchok JD. Immune Checkpoint Blockade in Cancer Therapy. Journal of clinical oncology. 2015; 33(17):1974-1982.

3. Chow LQ. Exploring novel immune-related toxicities and endpoints with immune-checkpoint inhibitors in non-small cell lung cancer. American Society of Clinical Oncology educational book / ASCO American Society of Clinical Oncology Meeting. 2013.

4. Bagley SJ, Bauml JM and Langer CJ. PD-1/PD-L1 immune checkpoint blockade in non-small cell lung cancer. Clinical advances in hematology \& oncology. 2015; 13(10):676683.

5. Gandini S, Massi D and Mandala M. PD-L1 expression in cancer patients receiving anti PD-1/PD-L1 antibodies: A systematic review and meta-analysis. Critical reviews in oncology/hematology. 2016; 100:88-98.

6. Rosenberg JE, Hoffman-Censits J, Powles T, van der Heijden MS, Balar AV, Necchi A, Dawson N, O’Donnell PH, Balmanoukian A, Loriot Y, Srinivas S, Retz MM, Grivas P, Joseph RW, Galsky MD, Fleming MT, et al. Atezolizumab in patients with locally advanced and metastatic urothelial carcinoma who have progressed following treatment with platinum-based chemotherapy: a single-arm, multicentre, phase 2 trial. Lancet (London, England). 2016; 387(10031):1909-1920.
7. Passiglia F, Bronte G, Bazan V, Natoli C, Rizzo S, Galvano A, Listi A, Cicero G, Rolfo C, Santini D and Russo A. PD-L1 expression as predictive biomarker in patients with NSCLC: a pooled analysis. Oncotarget. 2016; 7(15):1973847. doi: 10.18632/oncotarget.7582.

8. Taube JM, Klein A, Brahmer JR, Xu H, Pan X, Kim JH, Chen L, Pardoll DM, Topalian SL and Anders RA. Association of PD-1, PD-1 ligands, and other features of the tumor immune microenvironment with response to antiPD-1 therapy. Clinical cancer research. 2014; 20(19):50645074.

9. Tumeh PC, Harview CL, Yearley JH, Shintaku IP, Taylor EJ, Robert L, Chmielowski B, Spasic M, Henry G, Ciobanu V, West AN, Carmona M, Kivork C, Seja E, Cherry G, Gutierrez AJ, et al. PD-1 blockade induces responses by inhibiting adaptive immune resistance. Nature. 2014; 515(7528):568-571.

10. Larkin J, Chiarion-Sileni V, Gonzalez R, Grob JJ, Cowey CL, Lao CD, Schadendorf D, Dummer R, Smylie M, Rutkowski P, Ferrucci PF, Hill A, Wagstaff J, Carlino MS, Haanen JB, Maio M, et al. Combined Nivolumab and Ipilimumab or Monotherapy in Untreated Melanoma. The New England journal of medicine. 2015; 373(1):23-34.

11. Taube JM, Anders RA, Young GD, Xu H, Sharma R, McMiller TL, Chen S, Klein AP, Pardoll DM, Topalian SL and Chen L. Colocalization of inflammatory response with B7-h1 expression in human melanocytic lesions supports an adaptive resistance mechanism of immune escape. Science translational medicine. 2012; 4(127):127ra137.

12. Madore J, Vilain RE, Menzies AM, Kakavand H, Wilmott JS, Hyman J, Yearley JH, Kefford RF, Thompson JF, Long GV, Hersey P and Scolyer RA. PD-L1 expression in melanoma shows marked heterogeneity within and between patients: implications for anti-PD-1/PD-L1 clinical trials. Pigment cell \& melanoma research. 2015; 28(3):245-253.

13. Lee SJ, Jang BC, Lee SW, Yang YI, Suh SI, Park YM, Oh S, Shin JG, Yao S, Chen L and Choi IH. Interferon regulatory factor-1 is prerequisite to the constitutive expression and IFN-gamma-induced upregulation of B7H1 (CD274). FEBS letters. 2006; 580(3):755-762.

14. Dong H, Zhu G, Tamada K and Chen L. B7-H1, a third member of the B7 family, co-stimulates T-cell proliferation and interleukin-10 secretion. Nature medicine. 1999; 5(12):1365-1369.

15. Sznol M and Chen L. Antagonist antibodies to PD-1 and B7-H1 (PD-L1) in the treatment of advanced human cancer. Clinical cancer research. 2013; 19(5):1021-1034.

16. Kerr KM, Tsao MS, Nicholson AG, Yatabe Y, Wistuba, II and Hirsch FR. Programmed Death-Ligand 1 Immunohistochemistry in Lung Cancer: In what state is this art? Journal of thoracic oncology. 2015; 10(7):985-989.

17. Kaptain S, Tan LK and Chen B. Her-2/neu and breast cancer. Diagnostic molecular pathology. 2001; 10(3):139152. 
18. Bang YJ, Van Cutsem E, Feyereislova A, Chung HC, Shen L, Sawaki A, Lordick F, Ohtsu A, Omuro Y, Satoh T, Aprile G, Kulikov E, Hill J, Lehle M, Ruschoff J and Kang YK. Trastuzumab in combination with chemotherapy versus chemotherapy alone for treatment of HER2-positive advanced gastric or gastro-oesophageal junction cancer (ToGA): a phase 3, open-label, randomised controlled trial. Lancet (London, England). 2010; 376(9742):687-697.

19. Meng X, Huang Z, Teng F, Xing L and Yu J. Predictive biomarkers in PD-1/PD-L1 checkpoint blockade immunotherapy. Cancer treatment reviews. 2015; 41(10):868-876.

20. Sabatier R, Finetti P, Mamessier E, Adelaide J, Chaffanet M, Ali HR, Viens P, Caldas C, Birnbaum D and Bertucci F. Prognostic and predictive value of PDL1 expression in breast cancer. Oncotarget. 2015; 6(7):5449-5464. doi: 10.18632/oncotarget.3216.

21. Rizvi NA, Hellmann MD, Snyder A, Kvistborg P, Makarov V, Havel JJ, Lee W, Yuan J, Wong P, Ho TS, Miller ML, Rekhtman N, Moreira AL, Ibrahim F, Bruggeman C, Gasmi B, et al. Cancer immunology. Mutational landscape determines sensitivity to PD-1 blockade in nonsmall cell lung cancer. Science (New York, NY). 2015; 348(6230):124-128.

22. Gubin MM, Zhang X, Schuster H, Caron E, Ward JP, Noguchi T, Ivanova Y, Hundal J, Arthur CD, Krebber WJ, Mulder GE, Toebes M, Vesely MD, Lam SS, Korman AJ, Allison JP, et al. Checkpoint blockade cancer immunotherapy targets tumour-specific mutant antigens. Nature. 2014; 515(7528):577-581.

23. Brahmer J, Reckamp KL, Baas P, Crino L, Eberhardt WE, Poddubskaya E, Antonia S, Pluzanski A, Vokes EE, Holgado E, Waterhouse D, Ready N, Gainor J, Aren Frontera O, Havel L, Steins M, et al. Nivolumab versus Docetaxel in Advanced Squamous-Cell Non-Small-Cell Lung Cancer. The New England journal of medicine. 2015; 373(2):123-135.

24. Borghaei H, Paz-Ares L, Horn L, Spigel DR, Steins M, Ready NE, Chow LQ, Vokes EE, Felip E, Holgado E, Barlesi F, Kohlhaufl M, Arrieta O, Burgio MA, Fayette J, Lena $\mathrm{H}$, et al. Nivolumab versus Docetaxel in Advanced Nonsquamous Non-Small-Cell Lung Cancer. The New England journal of medicine. 2015; 373(17):1627-1639.

25. Herbst RS, Baas P, Kim DW, Felip E, Perez-Gracia JL, Han JY, Molina J, Kim JH, Arvis CD, Ahn MJ, Majem M, Fidler MJ, de Castro G, Jr., Garrido M, Lubiniecki GM, Shentu Y, et al. Pembrolizumab versus docetaxel for previously treated, PD-L1-positive, advanced non-smallcell lung cancer (KEYNOTE-010): a randomised controlled trial. Lancet (London, England). 2016; 387(10027):15401550.

26. Fehrenbacher L, Spira A, Ballinger M, Kowanetz M, Vansteenkiste J, Mazieres J, Park K, Smith D, Artal-Cortes A, Lewanski C, Braiteh F, Waterkamp D, He P, Zou W, Chen DS, Yi J, et al. Atezolizumab versus docetaxel for patients with previously treated non-small-cell lung cancer (POPLAR): a multicentre, open-label, phase 2 randomised controlled trial. Lancet (London, England). 2016.

27. Robert C, Long GV, Brady B, Dutriaux C, Maio M, Mortier L, Hassel JC, Rutkowski P, McNeil C, KalinkaWarzocha E, Savage KJ, Hernberg MM, Lebbe C, Charles $\mathrm{J}$, Mihalcioiu C, Chiarion-Sileni V, et al. Nivolumab in previously untreated melanoma without BRAF mutation. The New England journal of medicine. 2015; 372(4):320330.

28. Robert C, Schachter J, Long GV, Arance A, Grob JJ, Mortier L, Daud A, Carlino MS, McNeil C, Lotem M, Larkin J, Lorigan P, Neyns B, Blank CU, Hamid O, Mateus $\mathrm{C}$, et al. Pembrolizumab versus Ipilimumab in Advanced Melanoma. The New England journal of medicine. 2015; 372(26):2521-2532.

29. Postow MA, Chesney J, Pavlick AC, Robert C, Grossmann K, McDermott D, Linette GP, Meyer N, Giguere JK, Agarwala SS, Shaheen M, Ernstoff MS, Minor D, Salama AK, Taylor M, Ott PA, et al. Nivolumab and ipilimumab versus ipilimumab in untreated melanoma. The New England journal of medicine. 2015; 372(21):2006-2017.

30. Ribas A, Puzanov I, Dummer R, Schadendorf D, Hamid O, Robert C, Hodi FS, Schachter J, Pavlick AC, Lewis KD, Cranmer LD, Blank CU, O’Day SJ, Ascierto PA, Salama AK, Margolin KA, et al. Pembrolizumab versus investigator-choice chemotherapy for ipilimumab-refractory melanoma (KEYNOTE-002): a randomised, controlled, phase 2 trial. The Lancet Oncology. 2015; 16(8):908-918.

31. Weber JS, D'Angelo SP, Minor D, Hodi FS, Gutzmer R, Neyns B, Hoeller C, Khushalani NI, Miller WH, Jr., Lao CD, Linette GP, Thomas L, Lorigan P, Grossmann KF, Hassel JC, Maio M, et al. Nivolumab versus chemotherapy in patients with advanced melanoma who progressed after anti-CTLA-4 treatment (CheckMate 037): a randomised, controlled, open-label, phase 3 trial. The Lancet Oncology. 2015; 16(4):375-384.

32. Motzer RJ, Escudier B, McDermott DF, George S, Hammers HJ, Srinivas S, Tykodi SS, Sosman JA, Procopio G, Plimack ER, Castellano D, Choueiri TK, Gurney H, Donskov F, Bono P, Wagstaff J, et al. Nivolumab versus Everolimus in Advanced Renal-Cell Carcinoma. The New England journal of medicine. 2015; 373(19):1803-1813. 